\title{
In Silico Analyses of Rice Thionin Genes and the Antimicrobial Activity of OsTHION15 Against Phytopathogens
}

\author{
Krissana Boonpa, Suparuk Tantong, Kamonwan Weerawanich, Pawinee Panpetch, \\ Onanong Pringsulaka, Sittiruk Roytrakul, and Supaart Sirikantaramas ${ }^{\dagger}$
}

First author: Biotechnology Program, and second, third, fourth, and seventh authors: Department of Biochemistry, Faculty of Science, Chulalongkorn University, Bangkok 10330, Thailand; fifth author: Department of Microbiology, Faculty of Science, Srinakharinwirot University, Bangkok 10110, Thailand; sixth author: Genome Technology Research Unit, National Center for Genetic Engineering and Biotechnology, Klong Luang, Pathumthani, 12120, Thailand; and seventh author: Natural Product Biotechnology Research Unit, Chulalongkorn University.

Accepted for publication 17 July 2018

\begin{abstract}
Thionins are a family of antimicrobial peptides. We performed in silico expression analyses of the 44 rice (Oryza sativa) thionins (OsTHIONs). Modulated expression levels of OSTHIONs under different treatments suggest their involvement in many processes, including biotic, abiotic, and nutritional stress responses, and in hormone signaling. OsTHION15 (LOC_Os06g32600) was selected for further characterization based on several in silico analyses. OsTHION15 in O. sativa subsp. indica 'KDML 105' was expressed in all of the tissues and organs examined, including germinating seed, leaves, and roots of seedlings and mature plants, and inflorescences. To investigate the antimicrobial activity of

OsTHION15, we produced a recombinant peptide in Escherichia coli Rosetta-gami (DE3). The recombinant OsTHION15 exhibited inhibitory activities toward rice-pathogenic bacteria such as Xanthomonas oryzae pv. oryzae and Pectobacterium carotovorum pv. atroseptica, with minimum inhibitory concentrations of 112.6 and $14.1 \mu \mathrm{g} \mathrm{ml}^{-1}$, respectively. A significant hyphal growth inhibition was also observed toward Fusarium oxysporum f. sp. cubense and Helminthosporium oryzae. In addition, we demonstrated the in planta antibacterial activity of this peptide in Nicotiana benthamiana against $X$. campestris pv. glycines. These activities suggest the possible application of OsTHION15 in plant disease control.
\end{abstract}

Plant diseases are a threat to world agriculture and general food resources, and result in significant yield losses (Kenmore 1987; Teng and Gaunt 1980). On a global scale, the yield losses range from 20 to $40 \%$ of quantified crop production (Oerke 2006). Rice (Oryza sativa L.) is an important agricultural crop that is the staple food for several populations worldwide. In Asia, rice yield loss owing to pests and diseases was estimated at between 24 and $41 \%$ (Savary et al. 2000). The major diseases causing economic losses in rice-growing countries are bacterial blight caused by Xanthomonas oryzae pv. oryzae (Niño-Liu et al. 2006), bacterial leaf streak caused by X. oryzae pv. oryzicola (Niño-Liu et al. 2006), and seed-transmitted and bacterial sheath rot diseases caused by Pectobacterium carotovorum (Zhao et al. 2013). In addition, many serious rice diseases are caused by fungi such as root rot caused by Fusarium oxysporum (Saremi et al. 2011), brown leaf spot caused by Helminthosporium oryzae (Jatoi et al. 2016), and ufra disease caused by Ditylenchus angustus (Latif et al. 2011). To control diseases, various chemicals such as fungicides, bactericides (often called antibiotics), or nematicides have been extensively applied, depending on the targeted invasive organisms (Waard et al. 1993; Yamaguchi 2004). Nevertheless, chemical controls have several

†Corresponding author: S. Sirikantaramas; E-mail: supaart.s@chula.ac.th

Funding: The research was supported, in part, by the Thailand Research Fund (Chulalongkorn University fund and IRG578008) and the Chulalongkorn Academic Advancement into Its 2nd Century Project. The 90th Anniversary of Chulalongkorn University fund (Ratchadaphiseksomphot Endowment Fund to K. Boonpa) is gratefully acknowledged.

K. Boonpa and S. Tantong contributed equally to this work.

*The $\boldsymbol{e}$-Xtra logo stands for "electronic extra" and indicates that four supplementary figures and two supplementary tables are published online.

(C) 2019 The American Phytopathological Society disadvantages associated with bioaccumulation, and many bacterial and fungal pathogens develop resistance to chemical compounds.

Antimicrobial peptides (AMPs) are small, cysteine-rich peptides. They are naturally produced as host defense peptides against microbial invaders (Bolintineanu and Kaznessis 2011; De-Paula et al. 2008; Silverstein et al. 2007). AMPs have several advantages over antibiotics such as having more diverse antimicrobial activities, having the capability to specifically target the bacterial plasma membrane, and being unaffected by common mutations, which lead to antibiotic resistance (Hancock and Scott 2000). Thionins, a family of AMPs, are toxic to bacteria, fungi, yeast, and various mammalian cell types in vitro (Bohlmann et al. 1988; Carrasco et al. 1981; Fujimura et al. 2004). They can induce pathogen cell membrane leakage, resulting in antimicrobial and antifungal activities (Coulon et al. 2002; Thevissen et al. 1999). The overexpression of thionins can enhance plant resistance against a broad range of bacterial and fungal pathogens (Bohlmann and Broekaert 1994; Chan et al. 2005; Epple et al. 1997; Iwai et al. 2002; Muramoto et al. 2012; Shirasawa-Seo et al. 2002). Transgenic Carrizo plants (Arundo donax) expressing a modified thionin gene are less susceptible to X. citri infections (Hao et al. 2016). Arabidopsis thaliana thionin 2.4 (Thi2.4, At2g15010), which exhibits an antifungal activity, can be induced and accumulate in the cell wall after an $F$. graminearum inoculation. It is also found in the cell membranes of $F$. graminearum (Asano et al. 2013). Similarly, Iwai et al. (2002) reported that rice overexpressing Avena sativa thionin (Asthi1), which accumulates in the cell wall, revealed pathogenic bacterial staining only on the surface of stomata. Thus, thionins are effective in blocking bacterial attack at the target's surface (Asano et al. 2013; Iwai et al. 2002). Despite having potential applications, thionins have received less attention than other families of AMPs such as defensins. In rice, only one thionin has been functionally characterized. The transgenic O. sativa L. 'Nipponbare' overexpressing a thionin from rice, called OsTHI7 (LOC_Os06g32160), revealed a low susceptibility to the 
root pathogens Meloidogyne graminicola and Pythium graminicola (Ji et al. 2015), suggesting that the rice thionins (OsTHIONs) can efficiently control plant pathogens.

Because rice still possesses many uncharacterized thionins, in this study, we used gene expression data to identify all of the annotated OsTHIONs in the rice genome using in silico analyses. An uncharacterized thionin, OsTHION15, was selected to confirm its in vitro and in planta antimicrobial activities against phytopathogens. We suggest different biological functions for thionins and a potential use for OsTHION15 in disease control.

\section{MATERIALS AND METHODS}

Plant cultivation. Seed of Thai jasmine rice, $O$. sativa $\mathrm{L}$. subsp. indica 'KDML 105', were sterilized with $70 \%$ ethanol for $2 \mathrm{~min}$ and $15 \%$ bleach for $30 \mathrm{~min}$ with shaking. They were washed with sterile distilled water and immersed for 4 days in the dark. The water was changed daily. On day 5 , the coleoptiles were removed from the germinating seed for RNA extraction. The germinating seed continued growing in $0.5 \%$ Yoshida medium under the controlled conditions of $26^{\circ} \mathrm{C}$ with a relative humidity of $80 \%$ under a 6,000-lux light intensity with a cycle $16 \mathrm{~h}$ (day) and $8 \mathrm{~h}$ (night) for 2 weeks. The rice leaves and roots were collected from the seedlings for RNA extraction. After 1 month, some mature leaves and roots were collected for RNA extraction. The rest of the mature plants were then planted in clay pots and left outdoors until flowering. Nicotiana benthamiana seed were prepared for the in planta activity test. They were germinated in pots with peat moss and grown under controlled conditions of $25^{\circ} \mathrm{C}$ at a 4,000 -lux light intensity with a 16 -h photoperiod for 1.5 months. All of the plant materials were cultivated for three biological replicates for each experiment.

Microbial cultures. The bacterial and fungal indicators used in the antimicrobial assays were obtained from the DOAC Culture Collection Centre, Department of Agriculture, Ministry of Agriculture and Cooperatives, Thailand. They consisted of $X$. oryzae pv. oryzae (DOAC 4-1570, isolated from leaves of $O$. sativa L.), Pectobacterium carotovorum pv. atroseptica (DOAC 4-0039, isolated from tubers of Solanum tuberosum L.), F. oxysporum $\mathrm{f}$. $\mathrm{sp}$. cubense (DOAC 0110, isolated from pseudostems of Musa sapientum), and $H$. oryzae (DOAC 1570, isolated from leaves of $O$. sativa L.). For the in planta activity assay, $X$. campestris pv. glycines (TISTR 786) was obtained from the Thailand Institute of Scientific and Technological Research (TISTR) Culture Collection, Thailand.

In silico analyses. The genome of $O$. sativa subsp. japonica was searched for thionins using the Phytozome database (Goodstein et al. 2012) and the rice genome annotation project (Kawahara et al. 2013). The expression levels of OsTHIONs were determined in all rice tissues (seedlings, roots, mature and young leaves, and shoot apical meristem, as well as panicle [P2 to P6] and seed [S1 to S5] developmental stages) using the microarray database Rice eFP browser (Jain et al. 2007). The expression levels of OsTHIONs with greater than twofold changes $(P<0.05)$ under different treatment conditions were investigated using the Genevestigator tool (Hruz et al. 2008). The involvement of $O S T H I O N$ s with pathogen-responsive genes was analyzed using a coexpression network analysis available in the PlantArrayNet (Lee et al. 2009). The gene coexpression network was retrieved based on the correlation coefficient $(r$ value $) \geq 0.6$. The subcellular localization and the presence of a secretory signal peptides were predicted using WoLF PSORT (Horton et al. 2007) and SignalP (Petersen et al. 2011), respectively.

Quantitative reverse-transcription polymerase chain reaction analysis. Total RNA was extracted from rice samples of four different developmental stages-germinating seed, seedling, mature, and flowering - using an RNeasy Plant Mini Kit (Qiagen Inc, Hilden, Germany) according to the manufacturer's instructions. The cDNA was prepared using an iScript cDNA Synthesis Kit (Bio-Rad, Hercules, CA, USA) according to the manufacturer's instructions using $1 \mu \mathrm{g}$ of DNase-treated RNA as the template. Quantitative reverse-transcription polymerase chain reaction (qRT-PCR) was performed using $5 \mu \mathrm{l}$ of PerfeCTa SYBR Green FastMix (Quantabio, Beverly, MA), $2 \mu$ l of the diluted cDNA (20 ng of RNA), $2 \mu \mathrm{l}$ of nuclease-free water, and $10 \mu \mathrm{M}$ each primer in a total reaction volume of $10 \mu \mathrm{l}$. Thion15RT-F (5'-TGGCAAC GAAGAAGGGAAC- $3^{\prime}$ ) and thion15RT-R (5'-ACTCCAGGGCAG CATATATAG- $3^{\prime}$ ) were used as the forward and reverse primers, respectively, for the OsTHION15 amplification. The qRT-PCR conditions were as follows: $30 \mathrm{~s}$ at $95^{\circ} \mathrm{C}$ and 40 cycles of $5 \mathrm{~s}$ at $95^{\circ} \mathrm{C}$ and $10 \mathrm{~s}$ at $55^{\circ} \mathrm{C}$. Amplicon dissociation curves were recorded after cycle 40 by heating from 65 to $95^{\circ} \mathrm{C}$ with a ramp speed of $0.5^{\circ} \mathrm{C}$ for $0.15 \mathrm{~s}$. Relative gene expression levels were calculated by the comparative cycle threshold method (Schmittgen and Livak 2008) using $O s \mathrm{EF}-1 \alpha$ as an internal control gene. Each value was derived from three biological replicates $(P$ value $<0.05$, Tukey's honestly significant difference). The designed primers used to amplify $O s E F-1 \alpha$ were $O s E F 1 \alpha-\mathrm{F}$ ( $5^{\prime}$-ATGGTTGTGGAGACCTTC-3') and $O s E F 1 \alpha-\mathrm{R}\left(5^{\prime}-\mathrm{TCACCTTGGCACCGGTTG-} 3^{\prime}\right)$. The gene expression patterns in Thai jasmine rice were compared with those of Japanese rice in the Rice eFP browser (Jain et al. 2007) and Rice Expression Database (Xia et al. 2017).

Production of recombinant OsTHION in Escherichia coli. The cDNA of OsTHION15 (Supplementary Fig. S1) was used as a template. The primers were designed to exclude the signal peptide and to contain either BamHI or SalI restriction sites for manipulation (underlined): forward 5'-AAGGATCCATGCAAGA GACGATCAAGGTGGG- $3^{\prime}$ and reverse $5^{\prime}$-AAAGTCGACTTAG GAAACGATAGTGACAATATCAGCT- $3^{\prime}$. The expression vector was constructed by inserting amplified OSTHION15 into the vector pGEX-6P-3 to express glutathione S-transferase (GST)-fused OsTHION15. The correctly inserted constructs were verified by sequencing. pGEX-6P-3-OsTHION15 was transformed into competent Escherichia coli Rosetta-gami (DE3) that supports the formation of disulfide bonds in the peptides. A positive clone was inoculated into $5 \mathrm{ml}$ of Luria-Bertani (LB) medium supplemented with kanamycin at $50 \mu \mathrm{g} \mathrm{ml}^{-1}$, chloramphenicol at $34 \mu \mathrm{g} \mathrm{ml}^{-1}$, tetracycline at $100 \mu \mathrm{g} \mathrm{ml}-1$, and ampicillin at $100 \mu \mathrm{g} \mathrm{ml} \mathrm{m}^{-1}$. An overnight culture was inoculated and incubated at $37^{\circ} \mathrm{C}$ to an optical density at $600 \mathrm{~nm}\left(\mathrm{OD}_{600}\right)$ of 0.6. Then, the expression of GSTfused OsTHION15 was induced by the addition of isopropyl $\beta$-D-1thiogalactopyranoside (IPTG) to a final $0.1 \mathrm{mM}$ concentration and incubated at $37^{\circ} \mathrm{C}$ for $24 \mathrm{~h}$. The GST-fused OsTHION15 was purified from the supernatant using glutathione agarose bead affinity purification (Thermo Scientific, Rockford, IL, USA) according to the manufacturer's instructions. The PreScission protease (GE Healthcare, Chicago, IL, USA) was then applied to the spin column to cleave OsTHION15 from the fusion protein. The recombinant OsTHION 15 was analyzed by $12 \%$ tricine sodium dodecyl sulfate polyacrylamide gel electrophoresis (SDS-PAGE). The concentration of purified recombinant OsTHION15 was determined using a Bradford protein assay kit (Thermo Scientific) using bovine serum albumin as the standard. The protein sequence and the molecular mass of OsTHION15 were predicted using the ExPASy Translate tool and the ExPASy Compute $\mathrm{pI} / \mathrm{Mw}$ function, respectively (Gasteiger 2003).

Antimicrobial assay. The antibacterial activity of recombinant OsTHION15 was determined in terms of minimum inhibitory concentrations (MICs). The peptide was serially diluted with fresh tryptic soy broth (HiMedia Laboratories, Mumbai, India) at concentrations that varied from 450 to $0.88 \mu \mathrm{g} \mathrm{ml}{ }^{-1}$ in a microplate. Bacteria causing plant diseases $(X$. oryzae pv. oryzae and $P$. carotovorum pv. atroseptica) were grown in tryptic soy broth medium at $37^{\circ} \mathrm{C}$ overnight. These cell suspensions were subsequently inoculated into the wells to produce a final cell concentration of $5 \times$ $10^{5} \mathrm{CFU} \mathrm{ml}{ }^{-1}$. The culture was incubated overnight at $30^{\circ} \mathrm{C}$. The cell growth was determined from the $\mathrm{OD}_{600}$ using a Model 550 microplate reader (Bio-Rad), with and without ampicillin as positive and negative controls, respectively. 
The antifungal activities of the recombinant OsTHION15 were determined using the hyphal point technique (Bains and Bisht 1995). The fungal indicator strains $F$. oxysporum $\mathrm{f}$. sp. cubense and H. oryzae were grown on potato dextrose agar (PDA) plates at $30^{\circ} \mathrm{C}$ for 7 days. Agar plugs of actively growing cultures on PDA plates were excised using a $10-\mathrm{mm}$ sterile cork borer and placed on the center of new PDA plates supplemented with various concentrations of recombinant OsTHION15 (i.e., 7.0, 15.0, and $22.0 \mu \mathrm{g} \mathrm{ml}^{-1}$ ). This similar range of concentration was used to demonstrate the antifungal activity of pepper CaThi (Taveira et al. 2017). The inoculated plates were incubated at $30^{\circ} \mathrm{C}$ for 7 days. The hyphal growth was recorded daily as diameter. PDA plates without and with benzoic acid (Shabana et al. 2008) were used as negative and positive controls, respectively. All experiments for antimicrobial activity assays were carried out with at least three replicates $(P$ value $<0.05, t$ test $)$

In planta antibacterial activity. OsTHION15 was inserted into a plant expression vector using Gateway cloning technology. The full-length $O S T H I O N 15$, without a stop codon, was amplified from cDNA with the designed primers forward 5'-ATGAAAGGTGT GAAGAGTTTGATC-3' and reverse 5'-GGAAACGATAGTGA CAATATCA-3'. PCR amplification was performed with Phusion High-Fidelity DNA polymerase (New England Biolabs Inc., Ipswich, MA, USA) in a T100 Thermal Cycler (Bio-Rad). OsTHION15 was subsequently ligated using a pCR8/GW/TOPOTA Cloning kit (Invitrogen, Waltham, MA) before being integrated into the $\mathrm{C}$ terminal His-tagged destination vector pEAQ-HT-DEST3 (pEAQ3) (Peyret and Lomonossoff 2013) using LR Clonase II (Invitrogen) to generate the expression cassette pEAQ3-OsTHION15. This expression vector was then transformed into Agrobacterium tumefaciens GV3101 by electroporation.

To determine the in planta activity, A. tumefaciens harboring pEAQ3-OsTHION15 was cultured in LB medium containing a final concentration of kanamycin, rifampicin, and gentamycin at $50 \mu \mathrm{g}$ $\mathrm{ml}^{-1}$ each for 2 days at $30^{\circ} \mathrm{C}$. The pellet of $A$. tumefaciens harboring pEAQ3-OsTHION15 was collected and resuspended in the infiltration medium (10 mM morpholineethanesulfonic acid- $\mathrm{MgCl}_{2^{-}}$ acetosyringone buffer) to an $\mathrm{OD}_{600}$ of 2.0 and incubated at room temperature for 2 to $3 \mathrm{~h}$. The overnight culture of $X$. campestris was prepared to an $\mathrm{OD}_{600}$ of 0.4 . The cultures of A. tumefaciens harboring pEAQ3-OsTHION15 and X. campestris were mixed equally and coinfiltrated using a syringe onto leaves of 6-week-old $N$. benthamiana. The same leaf of $N$. benthamiana coinfiltrated with $A$. tumefaciens harboring the empty pEAQ3 vector and $X$. campestris was used as the positive control. The disease symptoms were observed for 8 days. The in planta activity assay was conducted with a minimum of three replicates of independent leaves.

\section{RESULTS}

In silico expression analyses of OsTHIONs. In the Phytozome database and the data from the rice genome annotation project, 44 OsTHIONs were annotated. All of the annotated genes and locus numbers are listed in Supplementary Table S1. We explored the expression levels of all 44 OsTHIONs in various rice tissues by in silico analysis using the Rice eFP browser (Jain et al. 2007). Of these OsTHIONs, the expression data of 34 genes could be retrieved. Seedling root, late stage inflorescence, and seed were the tissues in which relatively high expression levels were observed (Fig. 1). Most OsTHIONs showed organ-specific expression patterns, except $O s T H I O N 30$ and $O s T H I O N 36$, which were expressed throughout all of the tissues (Fig. 1). We further investigated the expression levels of OsTHIONs under different treatment conditions using data from microarray experiments available in the Genevestigator tool, with a criteria of more than twofold changes and $P<0.05$ (Fig. 2). Although microarray probes were not available for all of the OSTHIONs, 26 of the annotated OsTHIONs were covered in our Genevestigator analysis. OsTHION15,
OsTHION26, and OsTHION30 showed significant upregulation when infected with the causal agent of rice bacterial blight, $X$. oryzae pv. oryzae (Fig. 2). OsTHION15 showed an earlier upregulation than the other two thionins at $8 \mathrm{~h}$ postinfection in leaf. Similarly, OsTHION34 was upregulated after being infected by A. tumefaciens. The downregulation could be observed for OsTHION26, OsTHION29, OsTHION30, OsTHION32, OsTHION34, and OsTHION36 when infected with plant pathogens such as A. tumefaciens, Magnaporthe grisea, M. graminicola, M. incognita, $X$. oryzae, or an insect pest such as Nilaparvata lugens. Considering their antimicrobial activities, the genes upregulated during pathogen infection may be involved in defense mechanisms. Many OsTHIONs were also highly perturbed by abiotic stress. OsTHION15 showed a high level of upregulation under drought- and salt-stress conditions. OsTHION26 was upregulated under cold and heat treatments. Hormone treatments, chemical stresses, nutrient deprivation, gravistimulation, and imbibition also affect the expression levels of various $O s T H I O N$ s. In addition, OsTHION15 was highly expressed during stamen development.

We performed a gene coexpression network analysis to evaluate the involvement of OsTHIONs in plant defense mechanisms. Among the 44 identified OSTHIONs, the coexpression data of 15 OsTHIONs (OsTHION2, OsTHION7, OsTHION9, OsTHION15, OsTHION18, OsTHION24, OsTHION25, OsTHION26, OsTHION27, OsTHION29, OsTHION30, OsTHION32, OsTHION34, OsTHION36, and OsTHION39) were retrieved from PlantArrayNet (Lee et al. 2009). The groups of coexpressed genes containing those OsTHIONs are summarized in Supplementary Table S2. We found 10 OsTHIONs (OsTHION9, OsTHION15, OsTHION25, OsTHION26, OsTHION29, OsTHION30, OsTHION32, OsTHION34, OsTHION36, and $O s T H I O N 39$ ) that were coexpressed with plant-disease-resistant proteins, enzymes eliminating microbes (e.g., chitinase, glucanase, and amylase inhibitors), thaumatin-like proteins, and other AMP families. Some of the OsTHIONs were also coexpressed with genes involved in growth and development such as the rapid alkalinization factor proteins (Pearce et al. 2001) and the gibberellin-stimulated family of proteins (Aubert et al. 1998).

Based on the in silico analyses, we focused on the characterization of OsTHION15 because it was upregulated early upon $X$. oryzae pv. oryzae infection, coexpressed with genes known to participate in pathogen response processes such as genes encoding plant disease resistance proteins, pathogen-related proteins (X1), microbe-inhibiting enzymes (chitinase), and AMPs from other families (e.g., lipid transfer proteins, $\gamma$ purothionin, and glycinerich proteins). In addition, it was coexpressed with genes involved in the phenylpropanoid pathway such as phenylalanine ammonialyase and 4-coumarate CoA ligase (Fig. 3). This pathway leads to cell wall biosynthesis and secondary metabolite production, which also play roles during pathogen infections (Miedes et al. 2014; Piasecka et al. 2015).

The expression of OsTHION15 in Thai jasmine rice (O. sativa subsp. indica 'KDML 105'). OsTHION15 (408 bp) was predicted to encode 117 amino acids. We confirmed that the sequences of OsTHION15 from Japanese rice and that from Thai jasmine rice were the same. OsTHION15 was expressed in Thai rice in all of the tissues examined at four stages: germinating seed, seedling, maturity, and flowering. The highest expression level was detected in the flowering stage (Fig. 4). However, the expression pattern was different from those reported for OsTHION15 in the database, which showed no expression in either the seedling roots or in the leaves at the young and mature stages (Fig. 1).

Heterologous production of OsTHION15 in E. coli. OsTHION15 was predicted as an extracellular protein having a signal peptide cleavage site between Gln19 and Gln20. The signal peptide was excluded when the recombinant GST-fused OsTHION15 was produced in E. coli Rosetta-gami (DE3). The fusion protein was produced because it could reduce the cellular toxicity that may be caused by OsTHION15 and could be used for purification purposes. 
The optimal conditions for the production were $37^{\circ} \mathrm{C}$ for $24 \mathrm{~h}$ with a $0.1 \mathrm{mM}$ IPTG induction (Supplementary Fig. S2). The calculated molecular masses of the GST and OsTHION15 were 26 and $12.8 \mathrm{kDa}$, respectively. Thus, the expected molecular mass of GST-fused OsTHION 15 was approximately $39 \mathrm{kDa}$, which was observed using an SDS-PAGE analysis. After the purification and on-column GST cleavage, a 13-kDa purified recombinant OsTHION15 at 0.84 mg liter ${ }^{-1}$ was achieved (Supplementary Fig. S3).

In vitro and in planta antimicrobial activities of OsTHION15. The recombinant OsTHION15 peptide showed inhibitory activities against $X$. oryzae pv. oryzae and $P$. carotovorum, with MIC values of 112.6 and $14.1 \mu \mathrm{g} \mathrm{ml}^{-1}$, respectively. The antifungal activity against F. oxysporum f. sp. cubense showed a negative correlation, in which higher concentrations of OsTHION15 could reduce the hyphal growth of F. oxysporum f. sp. cubense (Fig. 5A). The hyphal growth of $F$. oxysporum f. sp. cubense significantly decreased from $87 \pm$ $0.7 \%$ at $7.0 \mu \mathrm{g} \mathrm{ml}^{-1}$ to $71 \pm 1.0 \%$ at $22.0 \mu \mathrm{g} \mathrm{ml}^{-1}$. This indicates that OsTHION15 exhibited a dose-independent inhibition against F. oxysporum f. sp. cubense. In addition, the various concentrations of OsTHION15 had similar effects on the hyphal elongation of H. oryzae (Fig. 5B). Moreover, OsTHION15 showed in planta antibacterial activity against $X$. campestris pv. glycines, a common pathogen used to infect Nicotiana benthamiana. The N. benthamiana leaves coinfiltrated with $A$. tumefaciens harboring the empty vector showed susceptibility to $X$. campestris. The leaves revealed gray necrosis, with a lesion diameter of $1.74 \pm 0.22 \mathrm{~cm}$ spreading over the infiltrated area at day 8 (Fig. 6, right). The symptom was slightly visible on the leaves coinfiltrated with the pathogen and with $A$. tumefaciens harboring OsTHION15, with a lesion diameter of $0.35 \pm 0.04 \mathrm{~cm}$ (Fig. 6, left). Although we did not detect the presence of OsTHION15 in the infiltrated $N$. benthamiana, we confirmed the expression of OsTHION15 (Supplementary Fig. S4). This indicates that OsTHION15 exhibited an in planta antibacterial activity against the $X$. campestris infection.

\section{DISCUSSION}

Although rice possesses as many as 44 thionins, only 1 OsTHION, OsThi7, is known to exhibit an antimicrobial activity (Ji et al. 2015), and several OsTHIONs are regulated by phytohormones (Kitanaga et al. 2006) and root-knot nematode infections ( $\mathrm{Ji}$ et al. 2015; Kyndt et al. 2012). Here, we further explored the annotated $O s T H I O N$ expression data from different publicly available databases. Of the 39 OsTHIONs, 15 OsTHIONs were highly expressed in seedling root, inflorescence, and seed (Fig. 1). However, the expression patterns of OSTHION15, which was a

magnitude of change $0250500750100012501500175020002250>2500$

greater than zero

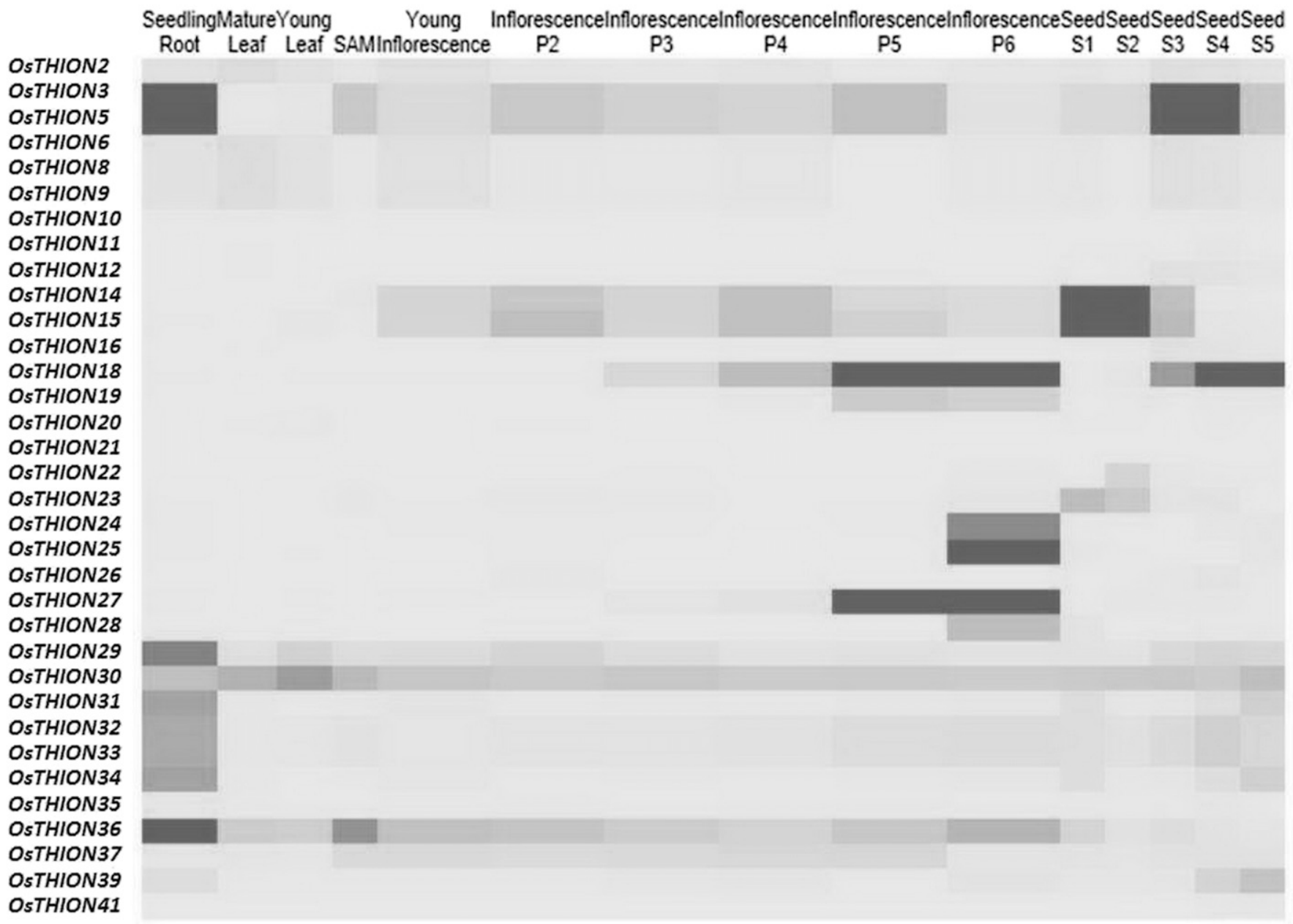

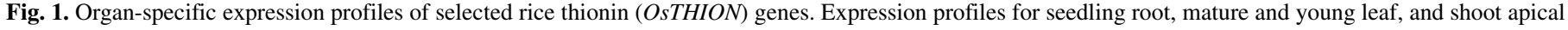

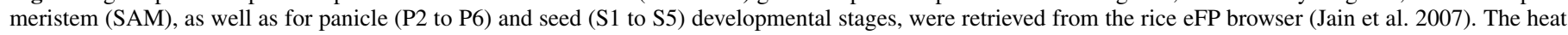

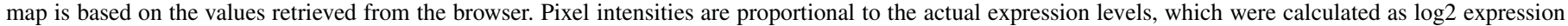
values. The bar indicates the magnitude of expression, from relatively low expression (gray) to high expression (black) levels. 
focus of this study, in Thai jasmine rice (Fig. 4) are different from those of Japanese rice in the database (Fig. 1), suggesting subspecies-specific expression patterns between indica and japonica types. The type with the high OsTHION expression level may exhibit less susceptibility to pathogens by blocking pathogen penetration because many OsTHIONs were predicted to be localized at the cell wall. A few cell-wall-bound thionins interact with pathogen cell membranes (Asano et al. 2013; Iwai et al. 2002). Although OsTHION15 expression could be detected in the mature leaves of Thai jasmine rice, this is still considered a cultivar susceptible to $X$. oryzae pv. oryzae. It is possible that (i) OsTHION15 is not induced quickly enough to initiate a defense mechanism, (ii) its expression level is not high enough to overcome the pathogen infection, or (iii) its inhibitory activity is not great enough against $X$. oryzae pv. oryzae.

Upon infection, OsTHION expression levels were modulated. Previous studies demonstrated the downregulation of OsTHIONs upon root-knot nematode $M$. graminicola infection. Kyndt et al. (2012) showed the downregulation of OsTHION5 and OsTHION7 at 3 days after infection. Ji et al. (2015) observed the downregulation of OsTHION1, OsTHION2, and OsTHION7+6 (the primers designed could bind to both OsTHION6 and OsTHION7) using a quantitative real-time PCR analysis in $M$. graminicola-induced galls at 7 days postinoculation. They suggested that the downregulation of the OSTHIONs is the consequence of the pathogen-mediated suppression of plant defense mechanisms, which contributes to a successful

$\log (2)$-ratio

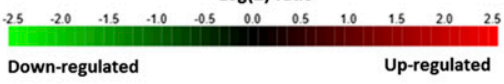

\begin{tabular}{|c|c|c|c|c|c|c|c|c|c|c|c|c|c|c|c|c|c|c|c|}
\hline \multirow{2}{*}{ Treatment } & \multirow{2}{*}{ Condition } & \multirow{2}{*}{ Tissue } & \multirow{2}{*}{ Cultivar } & \multirow{2}{*}{ Experiment ID } & \multicolumn{15}{|c|}{ OSTHION } \\
\hline & & & & & 10 & 12 & 15 & 25 & 26 & 28 & 29 & 30 & 31 & 32 & 33 & 34 & 35 & 36 & 37 \\
\hline \multicolumn{20}{|l|}{ Biotic } \\
\hline Agrobacterium tumefaciens & $6 \mathrm{~h}$ & Callus & Zhenshan 97 & Os-00037 & & & & & & & & & & & & & & & \\
\hline Magnaporthe graminicola & $12 \mathrm{~h}$ & Root & Nipponbare & Os-00079 & & & & & & & & & & & & & & & \\
\hline Magnaporthe grisea & $4 \mathrm{dpi}$ & Leaf & TP-PI54-15 & Os-00072 & & & & & & & & & & & & & & & \\
\hline Magnaporthe incognita & $6 \mathrm{dpi}$ & Root & Nipponbare & Os-00080 & & & & & & & & & & & & & & & \\
\hline Nilaparvata lugens & $8 \mathrm{hpi}$ & Stem & Taichung & Os-00073 & & & & & & & & & & & & & & & \\
\hline Xanthomonas oryzae pv. oryzae & $8 \mathrm{hpi}$ & Leaf & Huahui1 & Os-00070 & & & & & & & & & & & & & & & \\
\hline Xanthomonas oryzae pv. oryzae & $12 \mathrm{hpi}$ & Leaf & IR24 & Os-00055 & & & & & & & & & & & & & & & \\
\hline Xanthomonas oryzae pv. oryzae & $24 \mathrm{hpi}$ & Leaf & Nipponbare & Os-00061 & & & & & & & & & & & & & & & \\
\hline Xanthomonas oryzae pv. oryzicola & $2 \mathrm{dpi}$ & Flag leaf & 9804-Rxo1 & Os-00054 & & & & & & & & & & & & & & & \\
\hline \multicolumn{20}{|l|}{ Abiotic } \\
\hline Anoxia & aerobic germination, $24 \mathrm{~h}$ & Coleoptile & Nipponbare & Os-00009 & & & & & & & & & & & & & & & \\
\hline Anoxia & $\mathrm{N}_{2}, 24 \mathrm{~h}$ & Coleoptile & Nipponbare & Os-00051 & & & & & & & & & & & & & & & \\
\hline Cold & $4{ }^{\circ} \mathrm{C}, 3 \mathrm{~h}$ & Seedling & Nipponbare & Os-00008 & & & & & & & & & & & & & & & \\
\hline Cold & $4^{\circ} \mathrm{C}, 2 \mathrm{~h}$ & Shoot & C418 & Os-00102 & & & & & & & & & & & & & & & \\
\hline Cold & $4^{\circ} \mathrm{C}, 2 \mathrm{~h}$ & Leaf & IR29 & Os-00103 & & & & & & & & & & & & & & & \\
\hline Cold & $4^{\circ} \mathrm{C}, 2 \mathrm{~h}$ & Leaf & LTH & Os-00102 & & & & & & & & & & & & & & & \\
\hline Cold & $4^{\circ} \mathrm{C}, 30 \mathrm{~min}$ & Leaf & LTH & Os-00106 & & & & & & & & & & & & & & & \\
\hline Drought & $30 \%$ water content, $24 \mathrm{~d}$ & Leaf & Bala & Os-00039 & & & & & & & & & & & & & & & \\
\hline Drought & $35 \%$ water content, $24 \mathrm{~d}$ & Panicle & Zhenshan 97 & Os-00041 & & & & & & & & & & & & & & & \\
\hline Drought & $56 \%$ water content, $14 \mathrm{~d}$ & Plant & IR64 & Os-00046 & & & & & & & & & & & & & & & \\
\hline Drought & nowater, $3 \mathrm{~d}$ & Flag leaf & Kitaake & Os-00069 & & & & & & & & & & & & & & & \\
\hline Heat & $42^{\circ} \mathrm{C}, 3 \mathrm{~h}$ & Seedling & Nipponbare & Os-00024 & & & & & & & & & & & & & & & \\
\hline Heat & $45^{\circ} \mathrm{C}, 6 \mathrm{~h}$ & Leaf & Huahui 1 & Os-00070 & & & & & & & & & & & & & & & \\
\hline Salt & $60 \mathrm{mM} \mathrm{NaCl}, 3 \mathrm{~d}$ & Root & FL478 & Os-00023 & & & & & & & & & & & & & & & \\
\hline Salt & $150 \mathrm{mM} \mathrm{NaCl}, 24 \mathrm{~h}$ & Seedling & RILs & Os-00032 & & & & & & & & & & & & & & & \\
\hline \multicolumn{20}{|l|}{ Hormone } \\
\hline Abscisic acid & $100 \mu \mathrm{M}, 3 \mathrm{~h}$ & Seedling & Nipponbare & Os-00119 & & & & & & & & & & & & & & & \\
\hline Gibberellic acid & $100 \mu \mathrm{M}, 1 \mathrm{~h}$ & Seedling & Minghui 63 & Os-00037 & & & & & & & & & & & & & & & \\
\hline Gibberellic acid & $100 \mu \mathrm{M}, 1 \mathrm{~h}$ & Seedling & Zhenshan 97 & Os-00037 & & & & & & & & & & & & & & & \\
\hline Jasmonic acid & $100 \mu \mathrm{M}, 3 \mathrm{~h}$ & Seedling & Nipponbare & Os-00119 & & & & & & & & & & & & & & & \\
\hline Kinetin & $100 \mu \mathrm{M}, 1 \mathrm{~h}$ & Seedling & Zhenshan 97 & Os-00037 & & & & & & & & & & & & & & & \\
\hline Naphthalene acetic & $100 \mu \mathrm{M}, 1 \mathrm{~h}$ & Seedling & Minghui 63 & Os-00037 & & & & & & & & & & & & & & & \\
\hline Salicylic acid & $100 \mu \mathrm{M}, 3 \mathrm{~h}$ & Seedling & Nipponbare & Os-00119 & & & & & & & & & & & & & & & \\
\hline Trans-zealin & $5 \mu \mathrm{M}, 30 \mathrm{~min}$ & Root & Nipponbare & Os-00004 & & & & & & & & & & & & & & & \\
\hline \multicolumn{20}{|l|}{ Chemical } \\
\hline Arsenate & $100 \mu \mathrm{M}, 24 \mathrm{~h}$ & Shoot & Nipponbare & Os-00040 & & & & & & & & & & & & & & & \\
\hline Arsenate & $1 \mathrm{ppm}, 24 \mathrm{~h}$ & Root & Azucena & Os-00003 & & & & & & & & & & & & & & & \\
\hline Cadmium & $100 \mu \mathrm{M}, 24 \mathrm{~h}$ & Root & Nipponbare & Os-00040 & & & & & & & & & & & & & & & \\
\hline Cromium (VI) & $100 \mu \mathrm{M}, 24 \mathrm{~h}$ & Shoot & Nipponbare & Os-00040 & & & & & & & & & & & & & & & \\
\hline Lead & $100 \mu \mathrm{M}, 24 \mathrm{~h}$ & Shoot & Nipponbare & Os-00040 & & & & & & & & & & & & & & & \\
\hline \multicolumn{20}{|l|}{ Nutrient deprivation } \\
\hline Ammonium & $0.5 \mathrm{mM}, 10 \mathrm{~d}$ & Root & Nipponbare & Os-00121 & & & & & & & & & & & & & & & \\
\hline Iron & $\mathrm{noFe}, 10 \mathrm{~d}$ & Root & Nipponbare & Os-00036 & & & & & & & & & & & & & & & \\
\hline Iron and phosphorus & no Fe and $P, 10 d$ & Root & Nipponbare & Os-00036 & & & & & & & & & & & & & & & \\
\hline Phosphorus & noP, $10 \mathrm{~d}$ & Root & Nipponbare & Os-00036 & & & & & & & & & & & & & & & \\
\hline Phosphorus & noP, $10 \mathrm{~d}$ & Seedling & Nipponbare & Os-00091 & & & & & & & & & & & & & & & \\
\hline Phosphorus & no $P$ fertilizer, $10 \mathrm{~d}$ & Root & IR64 & Os-00096 & & & & & & & & & & & & & & & \\
\hline Potassium & nok, $3 \mathrm{~d}$ & Root & Nipponbare & Os-00101 & & & & & & & & & & & & & & & \\
\hline Potassium & noK, $5 \mathrm{~d}$ & Seedling & Nipponbare & Os-00115 & & & & & & & & & & & & & & & \\
\hline Others & & & & & & & & & & & & & & & & & & & \\
\hline Gravistimulation & $6 \mathrm{~h}$ & Shoot & Nipponbare & Os-00065 & & & & & & & & & & & & & & & \\
\hline Imbibition & $12 \mathrm{~h}$ & Embryo & Nipponbare & Os-00052 & & & & & & & & & & & & & & & \\
\hline Stamen development & stage 6 & Stamen & Nipponbare & Os-00118 & & & & & & & & & & & & & & & \\
\hline
\end{tabular}

Fig. 2. Genevestigator heat map for rice thionin $(O S T H I O N)$ expression under different treatments. The heat map presents the $O s T H I O N$ expression levels under various conditions. The Genevestigator analysis (Hruz et al. 2008) was completed with a probe set for 26 OsTHIONs. The intensity for each gene expression profile was normalized, with the upregulated, unchanged, and downregulated expression levels represented in different shades. Data shown are for those with expression values having greater than twofold changes or $P<0.05$. For OSTHION11, -18, -19, -20, -21, -22, -23, -24, -27, -38, and -41 , the expression values are either less than twofold changes or $P<0.05$. For $O$ STHION1, -2, -3, -4, -5, -6, -7, -8, -9, -13, -14, -16, -17, -39, -40, -42, -43, and -44, data are not presented due to probe unavailability. 
infestation. They then demonstrated that the overexpression of OsTHION7 in rice decreases its susceptibility to $M$. graminicola and the oomycete Pythium graminicola (Ji et al. 2015). Nevertheless, many pathogen-responsive genes are upregulated because of their important protective roles during infection (MacQueen and Bergelson 2016). Thus, in our study, we focused on the upregulated OsTHIONs (Fig. 2) that might be involved in pathogen responses because of their antimicrobial activities. A similar strategy was used to identify rice defensins with activities against plant pathogens (Tantong et al. 2016) and barley (Hordeum vulgare) thionins with activities against aphids (Escudero et al. 2017). In addition to fighting pathogen infection, roles for thionins in the defense against aphids have been recently established. The overexpression of thionins, which show an upregulation in barley after interactions with the phloem-feeding insects Myzus persicae and Rhopalosiphum padi, also increased resistance in $N$. benthamiana to $M$. persicae (Escudero et al. 2017). However, in the in silico analyses, we only observed the downregulation of OsTHIONs in rice stems invaded by the aphid Nilaparvata lugens (Fig. 2). Because of the incomplete expression data for all of the OsTHIONs, their involvement in response to aphid infestations cannot be fully determined. The high similarity levels among OsTHION family members at the nucleotide level has made it difficult to specifically design probes for each of the OsTHIONs.

The regulation of many OsTHIONs is also linked to several abiotic factors (e.g., cold, drought, heat, and salt), plant hormones,

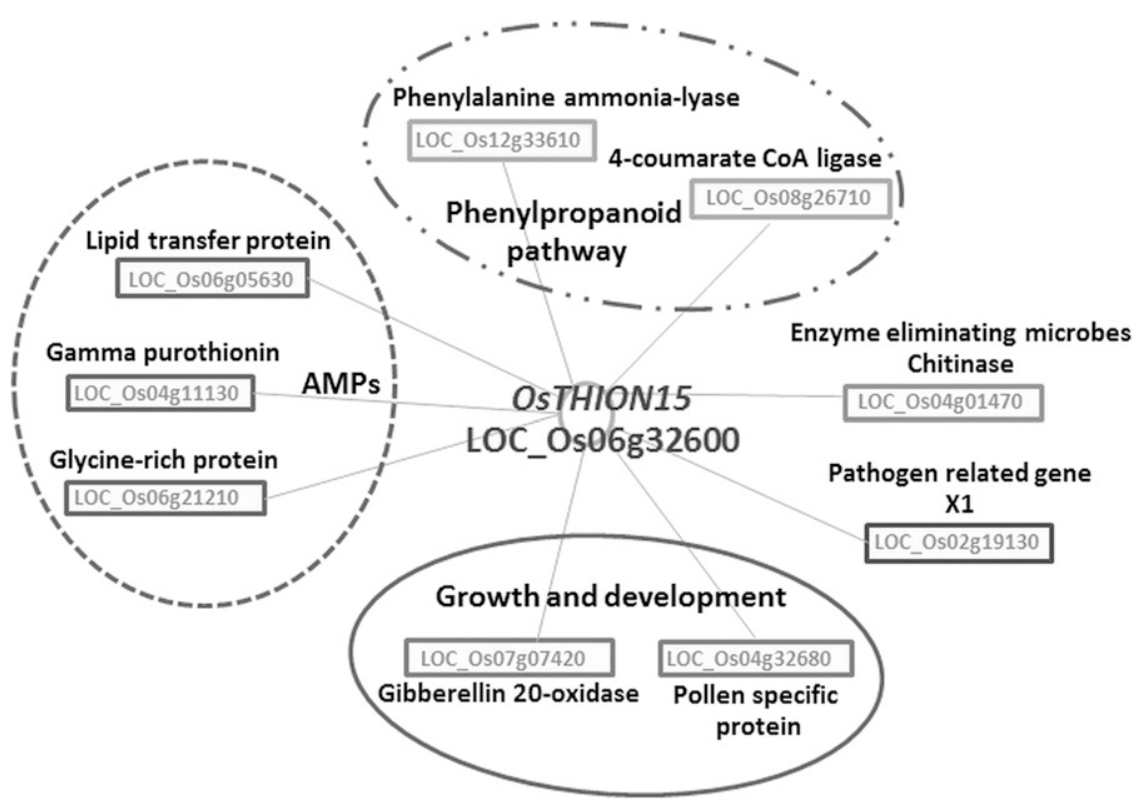

Fig. 3. Gene coexpression network analysis of rice thionin 15 (OsTHION15). Networks were analyzed using PlantArrayNet-Rice 300k. Coexpressed genes with the cut-off value for Pearson's correlation coefficient of 0.6 are presented in separate groups based on their predicted functions. The locus number of each gene is provided in the boxes. The closeness of their relationships is not represented in the networks.

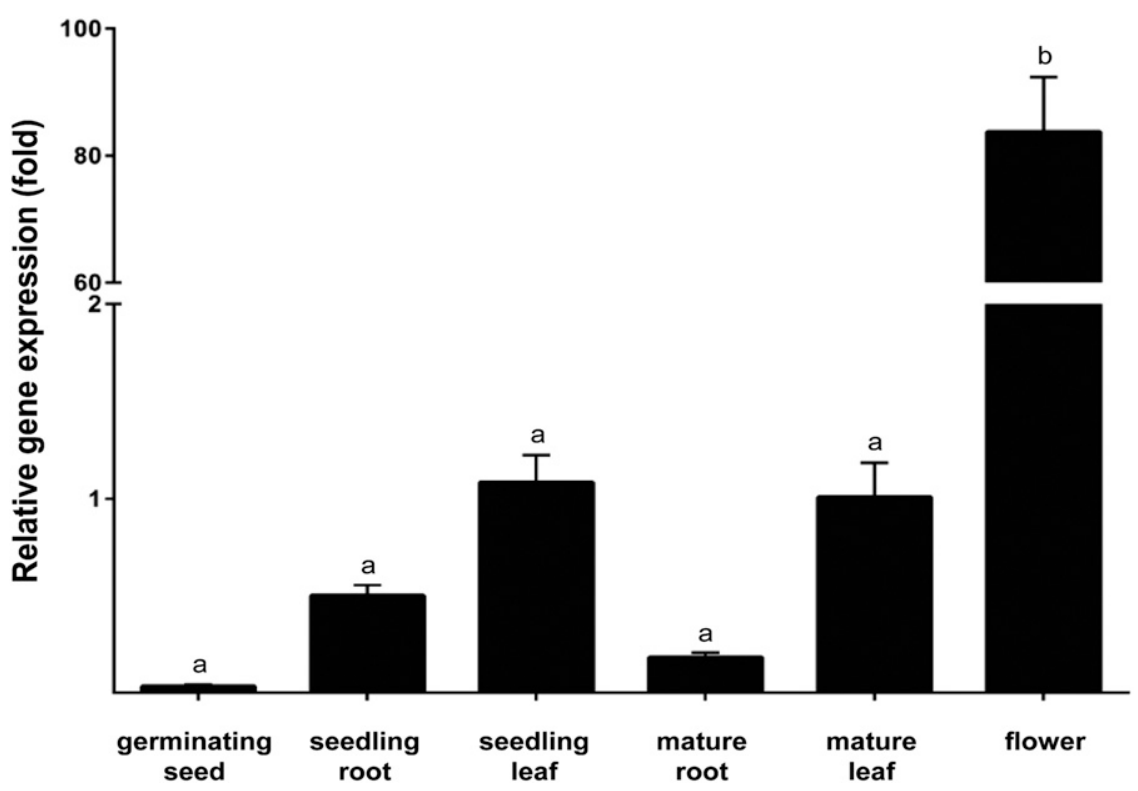

Fig. 4. Relative expression levels of rice thionin 15 (OsTHION15) in different stages and organs of Thai jasmine rice (Oryza sativa L. subsp. indica 'KDML 105'). Levels of $O S T H I O N 15$ were normalized to the reference gene, EF1 $\alpha$, and expressed as fold relative to the expression value of OsTHION15 in the mature leaf, which was given an arbitrary value of 1 . Significant statistics are shown by different letters $(P$ value $<0.05$, Tukey's honestly significant difference). Each value represents the mean \pm standard deviation $(n=3)$. 
and chemicals and to nutrient deprivation. To our knowledge, no information on the biological functions of thionins under many conditions is currently available. Nevertheless, an inverse correlation between gibberellic acid and several OSTHION expression levels has been documented (Kitanaga et al. 2006). In addition, indirect in planta evidence shows that some OsTHIONs are downregulated in the Meloidogyne graminicola-infected rice galls in which several gibberellin biosynthetic genes were activated (Kyndt et al. 2012). However, OsTHION15, which is the only OsTHION from the in silico analysis that is upregulated in the late stage of stamen development, might respond to gibberellin differently. Our coexpression analysis revealed the involvement of OsTHION15, which is coexpressed with gibberellin 20-oxidase, a biosynthetic enzyme involved in gibberellin biosynthesis, growth, and development (Fig. 3). These observations suggest a complex regulatory network involving the thionin family. Interestingly, Asano et al. (2013) reported that Arabidopsis' thionin (Thi2.4) exhibits not only an antifungal activity but also interacts with lectin in the fungal fruit body of $F$. graminearum to suppress its toxicity to plant cells. Thus, thionins appear to have extremely diverse functions in different plant processes. More studies are needed to provide a better understanding of the functions of the highly modulated thionins under various treatment conditions.

In this study, we functionally characterized OsTHION15, which is expressed throughout different developmental stages and in different organs, coexpressed with several pathogen-responsive genes, and upregulated upon $X$. oryzae pv. oryzae infection. Typically, a thionin contains an $\mathrm{N}$-terminal signal peptide for targeting to the endoplasmic reticulum, a positively charged mature domain with conserved cysteine residues and a C-terminal acidic peptide with no consistent motif. Thionins are produced as preproproteins that are usually processed to mature peptides (44 to 47 amino acids) of approximately $5 \mathrm{kDa}$ (Stec 2006). Nevertheless, a full-length OsTHION15 was predicted to contain a signal peptide of 19 amino acids and a mature peptide of 117 amino acids, with a molecular mass of $13 \mathrm{kDa}$ on tricine SDS-PAGE. Although C-terminal processing can increase the stability and solubility of many thionins (Romero et al. 1997), not all thionins require this modification. For

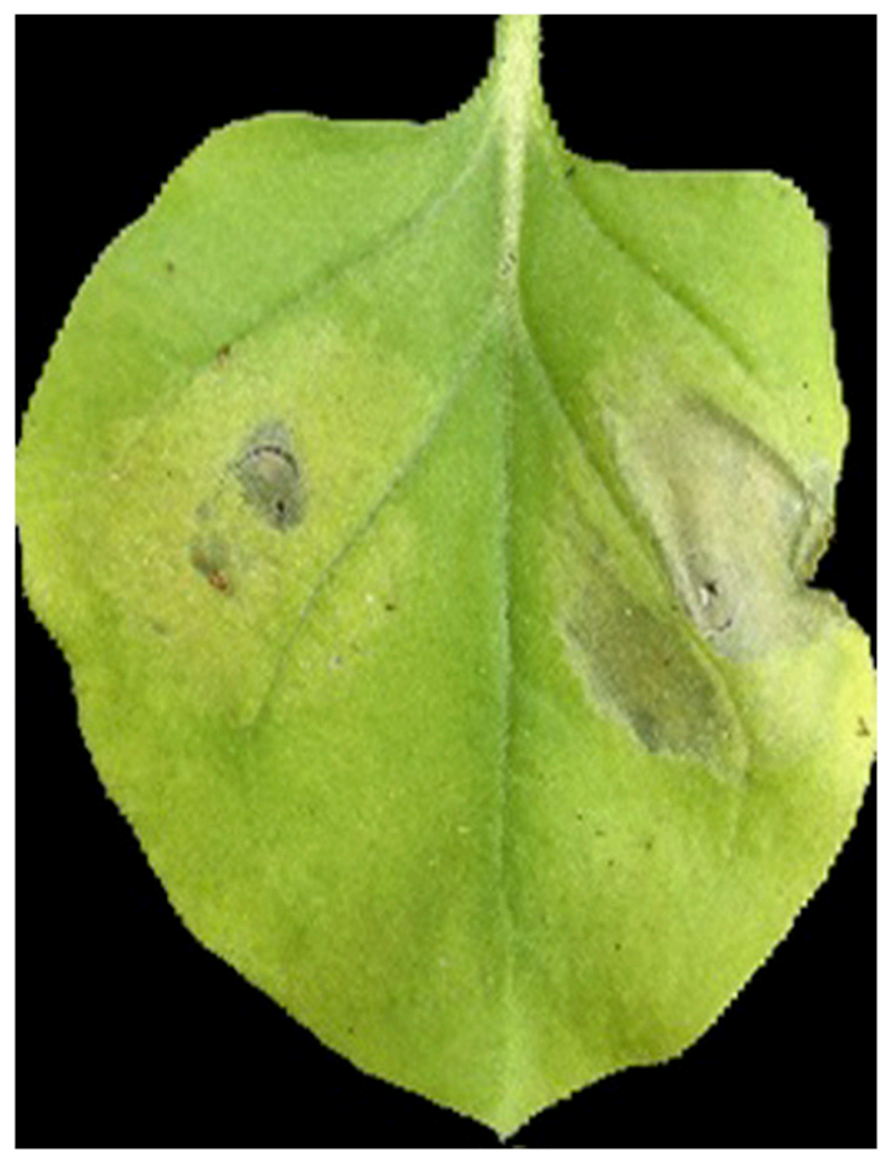

Fig. 6. In planta inhibitory activity of rice thionin 15 (OsTHION15). Symptoms were observed on the same Nicotiana benthamiana leaves after coinfiltrating with either Agrobacterium tumefaciens harboring pEAQ3-OsTHION15 (left) or the empty pEAQ3 vector (right), as a positive control, together with Xanthomonas campestris. At least three replicate tests were performed. The phenotype was photographed at 8 days after infiltration.
A

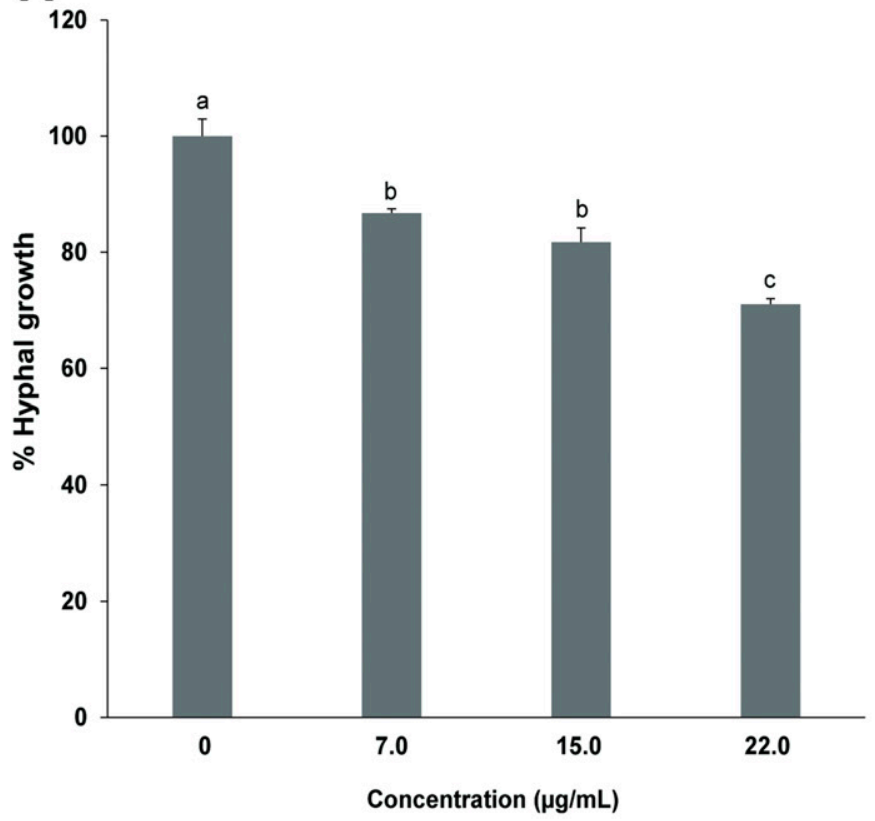

B

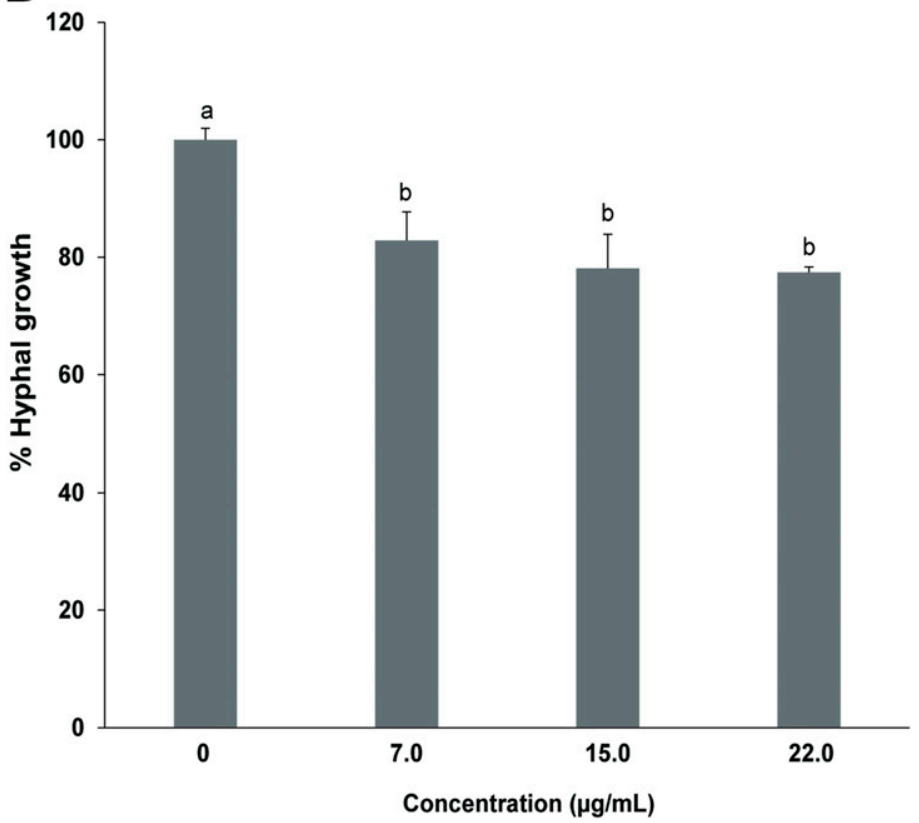

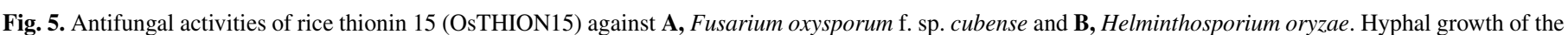

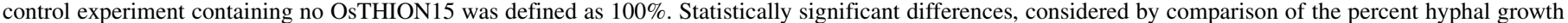
between treated and untreated control fungi, are shown by different letters ( $P$ value $<0.05, t$ test). 
example, Thi2.4 has a molecular mass of $15 \mathrm{kDa}$, which is the calculated mass, in Arabidopsis cells, indicating that processing did not occur in the $\mathrm{C}$-terminal region. This region may be important for its activity against the fungal pathogen $F$. graminearum (Asano et al. 2013). Although there is no in planta evidence for OsTHION15 processing, our study showed that unmodified OsTHION15 exhibits in vitro activities against several rice pathogens. The recombinant OsTHION15 had MIC values of 112.6 and $14.1 \mu \mathrm{g}$ $\mathrm{ml}^{-1}$ against $X$. oryzae pv. oryzae and Pectobacterium carotovorum pv. atroseptia, respectively, suggesting a relative high inhibitory activity against $P$. carotovorum pv. atroseptia. Additionally, at the lowest concentration used $\left(7.0 \mu \mathrm{g} \mathrm{ml}^{-1}\right)$, recombinant OsTHION15 reduced the hyphal growth of $F$. oxysporum f. sp. cubense and Helminthosporium oryzae to 87 and $83 \%$ of the control, respectively (Fig. 5). The viability levels of $F$. sporotrichioides and F. graminearum were significantly reduced when Thi 2.4 at 15 and $150 \mathrm{ng} \mathrm{ml}^{-1}$, respectively, was tested (Asano et al. 2013). Thionins from the endosperms of wheat and barley were more active against bacterial species such as Clavibacter michiganensis and Pseudomonas solanacearum than fungal pathogens such as Rosellinia necatrix, Colletotrichum lagenarium, and $F$. solani (Molina et al. 1993). Thionins AX1 and AX2 from sugar beet (Beta vulgaris) at 2 to $4 \mu \mathrm{g} \mathrm{ml}^{-1}$ were sufficient for the $50 \%$ growth inhibition of the fungi Cercospora beticola but they had limited effects against bacteria (Kragh et al. 1995). Thus, OsTHION15 could still be an antibacterial or antifungal peptide. Additionally, the overexpression of OsTHION15 exhibits an in planta inhibitory activity toward $X$. campestris in Nicotiana benthamiana. The expression vector used in our study, pEAQ-HT-DEST3, produces milligram levels of recombinant proteins in plants (Sainsbury et al. 2009), making the rapid screening for novel peptides or proteins involved in plant defense mechanisms possible. Therefore, in planta transient expression has received more attention recently (Holaskova et al. 2015; Niknejad et al. 2016). In addition, posttranslational modifications, if any, that can occur in plants might contribute to an increase in peptide or protein activity. Also, Stover et al. (2013) suggested that AMPs have higher in planta activities because of their ability to form smaller AMP aggregates, in contrast to larger aggregates formed in vitro that could interfere with their inhibitory functions. Thus, transgenic plants overexpressing OsTHION15 could develop resistance against pathogen infections.

In summary, our in silico analysis for AMPs suggested the involvement of OsTHIONs in several processes, in addition to pathogen responses, that have not been previously reported. We successfully produced recombinant OsTHION15 in bacteria and provided both in vitro and in planta evidence for its antimicrobial activities against several phytopathogens. This peptide could be of great practical interest for utilization as an agricultural microbicide against phytopathogens.

\section{ACKNOWLEDGMENTS}

We thank G. Lomonossoff (John Innes Centre, Norwich, UK) and Plant Bioscience Limited (Norwich, UK) for supplying the pEAQ vectors.

\section{LITERATURE CITED}

Asano, T., Miwa, A., Maeda, K., Kimura, M., and Nishiuchi, T. 2013. The secreted antifungal protein Thionin 2.4 in Arabidopsis thaliana suppresses the toxicity of a fungal fruit body lectin from Fusarium graminearum. PLoS Pathog. 9:e1003581.

Aubert, D., Chevillard, M., Dorne, A. M., Arlaud, G., and Herzog, M. 1998. Expression patterns of GASA genes in Arabidopsis thaliana: The GASA4 gene is up-regulated by gibberellins in meristematic regions. Plant Mol. Biol. 36:871-883.

Bains, P. S., and Bisht, V. S. 1995. Anastomosis group identity and virulence of Rhizoctonia solani isolates collected from potato plants in Alberta, Canada. Plant Dis. 79:241-242.

Bohlmann, H., and Broekaert, W. 1994. The role of thionins in plant protection. Crit. Rev. Plant Sci. 13:1-16.
Bohlmann, H., Clausen, S., Behnke, S., Giese, H., Hiller, C., and Schrader, G. 1988. Leaf-thionins of barley: A novel class of cell wall proteins toxic to plant-pathogenic fungi and possibly involved in the defence mechanism of plants. EMBO J. 7:1559-1565.

Bolintineanu, D. S., and Kaznessis, Y. N. 2011. Computational studies of protegrin antimicrobial peptides: A review. Peptides 32:188-201.

Carrasco, L., Vazquez, D., Hernandez-Lucas, P., Carbonero, C., and Garcia-Olmedo, F. 1981. Thionins: Plant peptides that modify membrane permeability in cultured mammalian cells. Eur. J. Biochem. 116:185-189.

Chan, Y. L., Prasad, V., Chen, K. H., Liu, P. C., Chan, M. T., and Cheng, C. P. 2005. Transgenic tomato plants expressing an Arabidopsis thionin (Thi2.1) driven by fruit-inactive promoter battle against phytopathogenic attack. Planta 221:386-393.

Coulon, A., Berkane, E., Sautereau, A. M., Urech, K., Rouge, P., and Lopez, A. 2002. Modes of membrane interaction of a natural cysteine-rich peptide: Viscotoxin A3. Biochim. Biophys. Acta 1559:145-159.

De-Paula, V. S., Razzera, G., Medeiros, L., Miyamoto, C. A., Almeida, M. S., Kurtenbach, E., Almeida, F. C. L., and Valente, A. P. 2008. Evolutionary relationship between defensins in the Poaceae family strengthened by the characterization of new sugarcane defensins. Plant Mol. Biol. 68:321-335.

Epple, P., Apel, K., and Bohlmann, H. 1997. Overexpression of an endogenous thionin enhances resistance of Arabidopsis against Fusarium oxysporum. Plant Cell 9:509-520.

Escudero, C., Morris, J. A., Hedley, P. E., and Bos, J. I. B. 2017. Barley transcriptome analyses upon interaction with different aphid species identifies thionins contributing to resistance. Plant Cell Environ. 27:2628-2643.

Fujimura, M., Ideguchi, M., Minami, Y., Watanabe, K., and Tadera, K. 2004. Purification, characterization and sequencing of novel antimicrobial peptides, Tu-AMP 1 and Tu-AMP 2, from bulbs of Tulip (Tulipa gesneriana L.). Biosci. Biotechnol. Biochem. 68:571-577.

Gasteiger, E. 2003. ExPASy: The proteomics server for in-depth protein knowledge and analysis. Nucleic Acids Res. 31:3784-3788.

Goodstein, D. M., Shu, S., Howson, R., Neupane, R., Hayes, R. D., Faso, J., Mitros, T., Dirks, W., Hellsten, U., Putnam, N., and Rokhsar, D. S. 2012. Phytozome: A comparative platform for green plant genomics. Nucleic Acids Res. 40:D1178-D1186.

Hancock, R. E. W., and Scott, M. G. 2000. The role of antimicrobial peptides in animal defenses. Proc. Natl. Acad. Sci. USA 97:8856-8861.

Hao, G., Stover, E., and Gupta, G. 2016. Overexpression of a modified plant thionin enhances disease resistance to citrus canker and Huanglongbing (HLB). Front. Plant Sci. 7:1078.

Holaskova, E., Galuszka, P., Frebort, I., and Oz, M. T. 2015. Antimicrobial peptide production and plant-based expression systems for medical and agricultural biotechnology. Biotechnol. Adv. 33:1005-1023.

Horton, P., Park, K. J., Obayashi, T., Fujita, N., Harada, H., Adams-Collier, C. J., and Nakai, K. 2007. WoLF PSORT: Protein localization predictor. Nucleic Acids Res. 35:W585-W587.

Hruz, T., Laule, O., Szabo, G., Wessendorp, F., Bleuler, S., Oertle, L., Widmayer, P., Gruissem, W., and Zimmermann, P. 2008. Genevestigator V3: A reference expression database for the meta-analysis of transcriptomes. Adv. Bioinf. 2008: Article 420747.

Iwai, T., Kaku, H., Honkura, R., Nakamura, S., Ochiai, H., Sasaki, T., and Ohashi, Y. 2002. Enhanced resistance to seed-transmitted bacterial diseases in transgenic rice plants overproducing an oat cell-wall-bound thionin. Mol. Plant-Microbe Interact. 15:515-521.

Jain, M., Nijhawan, A., Arora, R., Agarwal, P., Ray, S., Sharma, P., Kapoor, S., Tyagi, A. K., and Khurana, J. P. 2007. F-box proteins in rice genome-wide analysis, classification, temporal and spatial gene expression during panicle and seed development, and regulation by light and stress. Plant Physiol. 143:1467-1483

Jatoi, H. G., Abro, M. A., Tariq, J. A., Memon, S., Mangi, N., Maitlo, S. A., Kerio, A., Hussain, A., and Mengal, A. S. 2016. Efficacy of selected fungicides on the linear colony growth of the Helminthosporium oryzae caused by brown spot disease of rice. Pak. J. Biotechnol. 13:13-17.

Ji, H., Gheysen, G., Ullahi, C., Verbeek, R., Shang, C., De Vleesschauwer, D., Hofte, M., and Kyndt, T. 2015. The role of thionins in rice defence against root pathogens. Mol. Plant Pathol. 16:870-881.

Kawahara, Y., de la Bastide, M., Hamilton, J. P., Kanamori, H., McCombie, W. R., Ouyang, S., Schwartz, D. C., Tanaka, T., Wu, J., Zhou, S., Childs, K. L., Davidson, R. M., Lin, H., Quesada-Ocampo, L., Vaillancourt, B., Sakai, H., Lee, S. S., Kim, J., Numa, H., Itoh, T., Buell, C. R., and Matsumoto, T. 2013. Improvement of the Oryza sativa Nipponbare reference genome using next generation sequence and optical map data. Rice (N. Y.) 6:4.

Kenmore, P. E. 1987. Crop loss assessment in a practical integrated pest control program for tropical Asian rice. Pages 225-241 in: Crop Loss Assessment and Pest Management. P. S. Teng, ed. American Phytopathological Society, St. Paul, MN.

Kitanaga, Y., Jian, C., Hasegawa, M., Yazaki, J., Kishimoto, N., Kikuchi, S., Nakamura, H., Ichikawa, H., Asami, T., Ypshida, S., Yamaguchi, I., and 
Suzuki, Y. 2006. Sequential regulation of gibberellin, brassinosteroid, and jasmonic acid biosynthesis occurs in rice coleoptiles to control the transcript levels of antimicrobial thionin genes. Biosci. Biotechnol. Biochem. 70:2410-2419.

Kragh, K. M., Nielsen, J. E., Nielsen, K. K., Dreboldt, S., and Mikkelsen, J. D. 1995. Characterization and localization of new antifungal cysteine-rich proteins from Beta vulgaris. Mol. Plant-Microbe Interact. 8:424-434.

Kyndt, T., Denil, S., Haegeman, A., Trooskens, G., Bauters, L., Van Criekinge, W., De Meyer, T., and Gheysen, G. 2012. Transcriptional reprogramming by root knot and migratory nematode infection in rice. New Phytol. 196:887-900.

Latif, M. A., Ullah, M. W., Rafii, W. Y., and Taju, M. T. 2011. Management of ufra disease of rice caused by Ditylenchus angustus with nematicides and resistance. Afr. J. Microbiol. Res. 5:1660-1667.

Lee, T., Kim, Y., Thi, T., Pham, M., Song, S. I., Kang, K. Y., An, G., Jung, K., Galbraith, D. W., Kim, M., Yoon, U., and Nahm, B. H. 2009. RiceArrayNet: A database for correlating gene expression from transcriptome profiling, and its application to the analysis of coexpressed genes. Plant Physiol. 151:16-33.

MacQueen, A., and Bergelson, J. 2016. Modulation of $R$-gene expression across environments. J. Exp. Bot. 67:2093-2105.

Miedes, E., Vanholme, R., Boerjan, W., and Molina, A. 2014. The role of the secondary cell wall in plant resistance to pathogens. Front. Plant Sci. 5:358.

Molina, A., Ahl-Goy, P., Fraile, A., Sanchez-Monge, R., and Garcia-Olmedo, F. 1993. Inhibition of bacterial and fungal plant pathogens by thionins of types I and II. Plant Sci. 92:169-177.

Muramoto, N., Tanaka, T., Shimamura, T., Mitsukawa, N., Hori, E., Koda, K., Otani, M., Hirai, M., Nakamura, K., and Imaeda, T. 2012. Transgenic sweet potato expressing thionin from barley gives resistance to black rot disease caused by Ceratocystis fimbriata in leaves and storage roots. Plant Cell Rep. 31:987-997.

Niknejad, A., Webster, D., and Bhave, M. 2016. Production of bioactive wheat puroindoline proteins in Nicotiana benthamiana using a virus-based transient expression system. Protein Expr. Purif. 125:43-52.

Niño-Liu, D., Ronald, P. C., and Bogdanove, A. J. 2006. Xanthomonas oryzae pathovars: Model pathogens of a model crop. Mol. Plant Pathol. 7:303-324.

Oerke, E. C. 2006. Crop losses to pests. J. Agric. Sci. 144:31-43.

Pearce, G., Moura, D. S., Stratmann, J., and Ryan, C. A., Jr. 2001. RALF, a 5-kDa ubiquitous polypeptide in plants, arrests root growth and development. Proc. Natl. Acad. Sci. USA 98:12843-12847.

Petersen, T. N., Brunak, S., von Heijne, G., and Nielsen, H. 2011. SignalP 4.0: Discriminating signal peptides from transmembrane regions. Nat. Methods 8:785-786.

Peyret, H., and Lomonossoff, G. P. 2013. The pEAQ vector series: The easy and quick way to produce recombinant proteins in plants. Plant Mol. Biol. 83:51-58.

Piasecka, A., Jedrzejczak-Rey, N., and Bednarek, P. 2015. Secondary metabolites in plant innate immunity: Conserved function of divergent chemicals. New Phytol. 206:948-964.

Romero, A., Alamillo, J. M., and García-Olmedo, F. 1997. Processing of thionin precursors in barley leaves by a vacuolar proteinase. Eur. J. Biochem. 243:202-208.

Sainsbury, F., Thuenemann, E. C., and Lomonossoff, G. P. 2009. pEAQ: Versatile expression vectors for easy and quick transient expression of heterologous proteins in plants. Plant Biotechnol. 7:682-693.
Saremi, H., Okhovvat, S. M., and Ashrafi, S. J. 2011. Fusarium diseases as the main soil borne fungal pathogen on plants and their control management with soil solarization in Iran. Afr. J. Biotechnol. 10:18391-18398.

Savary, S., Willocquet, L., Elazegui, F. A., Castilla, N. P., and Teng, P. S. 2000. Rice pest constraints in tropical Asia: Quantification of yield losses due to rice pests in a range of production situations. Plant Dis. 84:357-369.

Schmittgen, T. D., and Livak, K. J. 2008. Analyzing real-time PCR data by the comparative $\mathrm{C}_{\mathrm{T}}$ method. Nat. Protoc. 3:1101-1108.

Shabana, Y. M., Ismail, A. E., Rashad, Y. M., and Survey, D. 2008. Control of brown spot pathogen of rice (Bipolaris oryzae) using some phenolic antioxidants. Braz. J. Microbiol. 39:438-444.

Shirasawa-Seo, N., Nakamura, S., Ukai, N., Honkura, R., Iwai, T., and Ohashi, Y. 2002. Ectopic expression of an oat thionin gene in carnation plants confers enhanced resistance to bacterial wilt disease. Plant Biotechnol. 19: 311-317.

Silverstein, K. A. T., Moskal, W. A., Wu, H. C., Underwood, B. A., Graham, M. A., Town, C. D., and VandenBosch, K. A. 2007. Small cysteine-rich peptides resembling antimicrobial peptides have been under-predicted in plants. Plant J. 51:262-280.

Stec, B. 2006. Plant thionins-The structural perspective. Cell. Mol. Life Sci. 63:1370-1385.

Stover, E., Stange, R. R., McCollum, T. G., Jaynes, J., Irey, M., and Mirkov, E. 2013. Screening antimicrobial peptides in vitro for use in developing transgenic citrus resistant to Huanglongbing and citrus canker. J. Am. Soc. Hortic. Sci. 138:142-148.

Tantong, S., Pringsulaka, O., Weerawanich, K., Meeprasert, A., Rungrotmongkol, T., Sarnthima, R., Roytrakul, S., and Sirikantaramas, S. 2016. Two novel antimicrobial defensins from rice identified by gene coexpression network analyses. Peptides 84:7-16.

Taveira, G. B., Mello, E. O., Carvalho, A. O., Regente, M., Pinedo, M., Canal, L. L., Rodrigues, R., and Gomes, V. M. 2017. Antimicrobial activity and mechanism of action of a thionin-like peptide from Capsicum annuum fruits and combinatorial treatment with fluconazole against Fusarium solani. Pept. Sci. 108:e23008.

Teng, P. S., and Gaunt, R. E. 1980. Modelling systems of disease and yield loss in cereals. Agric. Syst. 6:131-154.

Thevissen, K., Terras, F. R. G., and Broekaert, W. F. 1999. Permeabilization of fungal membrane by plant defensins and thionins inhibits fungal growth. Appl. Environ. Microbiol. 65:5451-5458.

Waard, M. A., Georgopoulos, S. G., Hollomon, D. W., Ishii, H., Leroux, P., Ragsdale, N. N., and Schwinn, F. J. 1993. Chemical control of plant diseases: Problems and prospects. Annu. Rev. Phytopathol. 31:403-421.

Xia, L., Zou, D., Sang, J., Xu, X., Yin, H., Li, M., Wu, S., Hu, S., Hao, L., and Zhang, Z. 2017. Rice Expression Database (RED): An integrated RNASeq-derived gene expression database for rice. J. Genet. Genomics 44: 235-241.

Yamaguchi, I. 2004. Overview on the chemical control of rice blast disease. Pages 1-13 in: Rice Blast: Interaction with Rice and Control. S. Kawasaki, ed. Kluwer Academic Publishers, Dordrecht, The Netherlands.

Zhao, Y., Li, P., Huang, K., Wang, Y., Hu, H., and Sun, Y. 2013. Control of postharvest soft rot caused by Erwinia carotovora of vegetables by a strain of Bacillus amyloliquefaciens and its potential modes of action. World J. Microbiol. Biotechnol. 29:411-420. 